\section{The Earliest Human Knowledge of Copper.}

THE first discovery of metals by man is usually described as having resulted from the association of the necessary materials in the construction of a primitive hearth on some chance occasion. At best, this explanation does not contradict our accumulated knowledge about the habits and conditions of early human life.

There seems to me to be quite another possibility, not necessarily antagonistic to the earlier one, which is the outcome of a recent communication from Sir Flinders Petrie (Ancient Egypt, June I926) on the Egyptian Paradise. $\mathrm{He}$ directs attention to the remarkable similarity of the place-names, the geography, and the "lakes of fire . . . in the midst of the paradise of cultivation" in the "Book of the Dead," with those of a definite region in the Caucasus - that along the rivers of the Iora and Kura. Then, following the normal lines of archæological argument, Sir Flinders suggests the possibility of the earliest Egyptian immigrants having come from that region.

It is known that some later arrivals, the earliest dynastic peoples, suddenly appeared in Egypt, equipped with a written language and with a knowledge of the working of metals, and of agriculture. If these constituted a later wave of wanderers from the same locality--just as there were several eruptions of tribes out of Arabia-they would bring with them knowledge naturally obtained from their home surroundings.

Copper occurs widespread throughout the Caucasian area. So also does petroleum; and the very locality in which Sir Flinders Petrie locates two lakes of fire and "a place of purification, probably by fire" from indications in the "Book of the Dead," is to-day occupied by an area of considerable richness in petroleum.

At one spot in a recent map ("Handbuch der regionalen Geologie," vol. v. pt. 5, heft 25, "Kaukasus," by v. Stahl, I923) copper and petroleum are shown as being to-day in close proximity. But there must be and must have been innumerable seepages of oil over the whole area, so that many other points of intimate contact between copper and petroleum must have existed since remote times.

This being so, when a petroleum spring or lake became ignited, as is known occasionally to have happened, there is the greatest likelihood of the adjacent copper being reduced by the high temperature of the reducing flame to the metal itself, to be discovered by man at some later date.

This suggestion is supported by the fact that copper was in use very early in the history of the country that is now known as Iraq ; this is also a petroliferous region, as is shown by the presence and use of bitumen from the earliest times.

It would be interesting to speculate on local results when other minerals were smelted in the same natural fashion, including the effect of the liberation of large quantities of arsenic or arsenic oxide over the surrounding country.

The Athenæum, August I9.

\section{The Zoological Names Simia, S. satyrus, and} Pithecus and their Possible Suppression.

UNDER the above heading in NATURE of July Io, p. 49 , Dr. C. W. Stiles gives a summary of the argument in support of a proposition to re-open the case of Simia before the International Commission on Zoological Nomenclature. Although in agreement with most of the general principles enumerated in his summary, we dissent from the view that the names Simia, S. satyrus, and Pithecus are ambiguous and

$$
\text { NO. 2968, VOL. } \text { I I } 8]
$$

"so confused in zoological literature as to preclude hope of reasonable uniformity in their use in zoological, bacteriological, serological and public health work.'

With regard to Simia for the orang, the name is supported by the many mammalogists who signed the list of "Nomina Conservanda" published in the Proc. Zool. Soc., London, I924, p. 345 . It is consistently used by naturalists in general. To suppose that bacteriological and medical writers (at all events those on this side of the Atlantic) would accept and use such a completely unknown name as "Pongo" for the orang is to show ignorance of the mentality and prejudices of the very workers for whose benefit the argument is professedly framed. For such writers, past, present, or future, Simia satyrus is the name of the orang, free from all ambiguity whatsoever, and with that widely signed "Nomina Conservanda" list to support them they would certainly regard 'Pongo' as ' Jazz' - and go their old way.

The fact that Dr. Elliot, in his bulky work on Primates, has used another name, would seem to have unduly influenced those who framed the argument outlined by Dr. Stiles; but unfortunately that work is so full of errors that as a standard of nomenclature it is repudiated by systematists in general.

The same has to be said about Pithecus, which is the technically correct name of the langurs, but has been wrongly used in another sense-for the macaques by Dr. Elliot alone among mammalogists. This wrong use has received no acceptance whatever, and cannot be said to render the name Pithecus ambiguous or unsuitable for acceptance by medical and other writers.

We would therefore reiterate our opinion that Simia satyrus for the orang, and Pithecus for the langurs fulfil the demand for names which are "thoroughly unambiguous and suitable."

Moreover Macaca, for which, according to the letter of Dr. Stiles, Pithecus would be abolished as the name of the macaques, should be, and is, used for these very animals, side by side with Pithecus for the langurs.

Arguments in favour of Simia for the orang are to be found in the Fiat lists above referred to, and for Pithecus in a paper by Thomas in the Ann. Mag. N. H. (8) xvii. p. I79, I9I6. OldField ThOMAS.

British Museum (Natural History), Martin A. C. Hinton. Cromwell Road, London, S.W.

\section{Lead Hydrogen Arsenate as a Mineral.}

A SPECIMEN from the Tsumeb mines in the Otavi district, South-West Africa, recently acquired for the Mineral Collection of the British Museum, shows colourless transparent crystal plates with brilliant lustre, which had been labelled 'lanarkite.' The largest of these are $\mathrm{I} \mathrm{cm}$. across with a thickness of I $\mathrm{mm}$. They rest on a crust of bayldonite pseudomorphous after mimetite (chloro-arsenate of lead), chessylite, and large crystals of anglesite $\left(\mathrm{PbSO}_{4}\right)$. The crystals are monoclinic $(a: b: c=0.8643: \mathrm{I}: 0.7 \times 8 \mathrm{I}$, $\beta=84^{\circ} 36^{\prime}$ ) and show a development of sixteen crystal-forms. These forms have been listed to show the angles from each to the three axial planes; and it is believed that such a method of tabulation may effect a compromise between the method of giving interfacial angles in zones and that of longitude and latitude $(\phi$ and $\rho$ ) angles employed in two-circle goniometry. The crystals are optically positive, and the optic axial plane is perpendicular to the plane of symmetry and direction of good cleavage. The 